\title{
MUDFLOW FLOODING SIMULATION AND SOLUTION PROPOSAL IN A VALLEY IN THE SOUTH OF PERU
}

\author{
ANDRÉS V. PÉREZ ${ }^{1 *}$, REYNA HUANCARA ${ }^{1}$, FLOR CUTIRE ${ }^{1}$, NATALY PEREZ $^{2} \&$ ANAI PEREZ ${ }^{3}$ \\ ${ }^{1}$ National University of Saint Agustin, Civil Engineering School, Peru \\ ${ }^{2}$ Duke University, Pratt School Engineering, USA \\ ${ }^{3}$ Columbia University, Graduate School of Architecture, Planning and Preservation, USA
}

\begin{abstract}
Due to the 'El Niño' phenomenon, intense rains occur from January to March on the entire coast of Peru, producing mudflows which flood the coastal valleys, generating great problems for the agriculture of the place by flooding the crops, as well as the obstruction of one of the main highways that connect this part of the country. In this research, a two-dimensional computational simulation of this mudflow flood is carried out, in a Valley called 'Los Pescadores'. Previously, for this simulation, information and data from the valley were collected, such as the topography, rheology, roughness of soils, as well as the hydrology of the basin of this valley. The flooding flow is a concentration of water and sediment; this corresponds to a non-Newtonian flow. After calibrating the simulation, a solution proposal is presented, in which it is proposed to channel the river that crosses this valley with an embankment dam and the construction of a bridge over the main road. Subsequently, the mudflow was simulated again with the proposed hydraulic structures, obtaining a satisfactory solution. With the final simulation, the magnitude of the flow, the depth, flow velocities and the length of the dike were calculated, as well as the length of the bridge. Finally, the cost of the proposed solution was determined.

Keywords: embankment, flooding, hydrology, mudflow, South Peru, two-dimensional simulation.
\end{abstract}

\section{INTRODUCTION}

Peru, due to its geographical location, is affected by the 'El Niño' phenomenon in the summer seasons due to the fact that at this season there are several maximum rainfall events, generating floods and mudflows throughout our territory, causing large economic losses and even deaths of human lives (Fig. 1).

In 2017, due to the 'El Niño' phenomenon, thousands of kilometres of roads were destroyed and more than 200 bridges collapsed, leaving entire towns uncommunicated. The damage was estimated at more than US \$3,000 million according to Macroconsult [1].

The flows known as 'huaycos' or mudflow, in Peru have a great destructive power due to the solid material that they transport, reaching densities up to $2,400 \mathrm{~kg} / \mathrm{m}^{3}$. This is why the importance of investigating this type of flow in order to predict their behaviour and take the appropriate preventive measures based on the analysis of two-dimensional models.

One of the places where occurs with greater frequency and intensity is in the Arequipa region, specifically in a valley called 'Los Pescadores', at km $756+400$ of the Panamericana Sur highway.

The use of hydraulic numerical models facilitates the task of calculating complex equations that govern hyper-concentrated flows.

*ORCID: https://orcid.org/0000-0002-3404-4349 


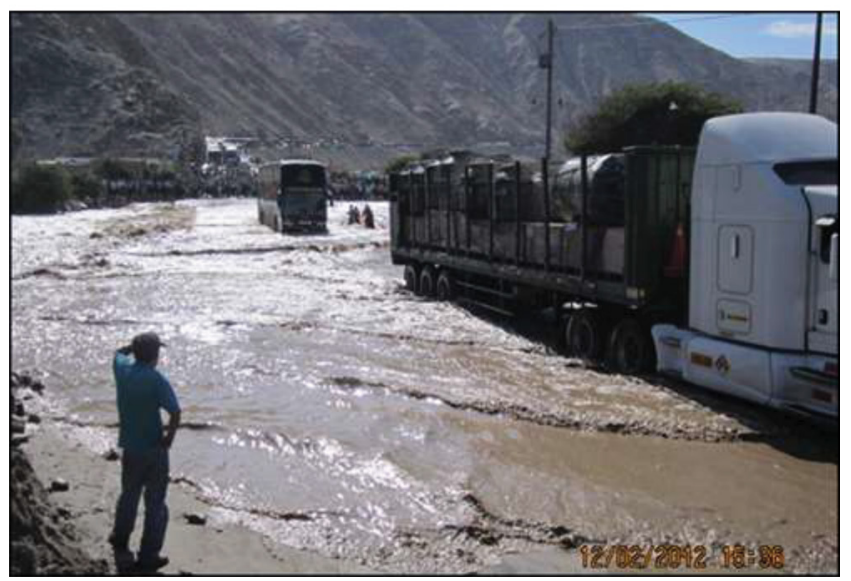

Figure 1: Restricted traffic in the Panamericana Sur-Los Pescadores, occurred on 12 February 2012 (3:36 pm). Source: PROVIAS, 2012.

\section{METHODS AND MATERIALS}

The equations that govern the phenomenon of mudflow are the equations of continuity and momentum of water considering the convective acceleration in a transitory state $(t)$ and in two dimensions $(x, y)$; To the previously mentioned equations, we must add the volumetric concentration equations of water and sediment in the form of viscosity $(\eta)$ composed of water and sediments plus the yield stress $\left(\tau_{y}\right)$; these considerations make the mudflow a non-Newtonian flow. The rheological model that is considered in this research is the quadratic model of O'Brien and Julien [2].

The mudflow involves complex phenomena of fluid and sediment interaction such as turbulence, viscous shear stresses, particle momentum exchange, collision of sediment particles, and erosion and rotation in their movement one after another. O'Brien \& Julien investigated this type of flow in the Laboratory of Analysis of Mudflow Properties, 1988 [3] and Julien \& Lan, 1991 [4]. These studies indicate that the sludge flow behaves like Bingham-type fluids with low deformation velocities. The rheological parameters for the simulation will be determined later.

\subsection{Numerical solution of the model}

Due to that the governing continuity and momentum equations are two-dimensional partial differential equations that do not admit an analytical solution, these are solved with numerical methods, in this case by the finite differences method, through the central scheme.

The numerical finite difference schemes transform the differential equations to a set of systems of linear simultaneous equations, calculating the velocities in the $X, Y$ direction and the depth as a function of increments of $\Delta x, \Delta y$ and $\Delta t$, which is the pass of the time. For the solution by the finite difference method, an explicit scheme was used; this requires small increments for the convergence of the numerical procedure and for the numerical stability of the calculations. Furthermore, a necessary but not an enough condition for the stability of an explicit schema is to respect the condition of the Courant-Friedrich-Lewy number [5]. According to Castillo Navarro [6], the pass of the time $\Delta t$ generally varies from 0.1 second 
to 60 seconds. After many tests fulfilling the necessary conditions, it was determined that the size of the grid should be $\Delta x=3.0 \mathrm{~m}$ and $\Delta y=3.0$, resulting in 330,000 square grid.

2.2 Valley and basin data for simulation

For the mudflow simulation, the following studies were required: the digital terrain elevation topography - DEM, the geometry of the riverbed, estimated values of the Manning roughness of the riverbed and the floodplain, inlet hydrograph (liquids and solids concentration) and rheological parameters of the water-sediment mixture, which are described below.

\subsubsection{Topography of the flooded valley}

The topographic survey of the Valley called 'Los Pescadores' was carried out with the help of an eBee RTK drone and differential GPS with reference to the geodetic point PCR-3 of order 'B'. The coordinate system used was the Universal Transverse Mercator (UTM) [7].

The flight plan was programmed by taking into account various factors such as the covered area, wind and battery, making a total of 16 flights. The results of the drone flight for the topographic survey of the terrain can be viewed in Table 1 .

Finally, the topographic plan was obtained with minor contour lines every $1.0 \mathrm{~m}$ and major contour lines every $5.0 \mathrm{~m}$ as can be seen in Fig. 2. DEM information was required for the simulation of the flood model. In addition, it can be visualized in the plan, the location of the sampling points to determine the rheological parameters and the soil mechanics study.

\subsubsection{Rheology of the flood zone}

For the mudflow simulation, it is necessary to have rheological data, for this, several samples were taken in the flooded area (Fig. 3). The results of the mechanical properties of sample M1, after soil laboratory tests, are presented in Table 2.

The law that governs rheological parameters are those defined by O'Brien and Julien (O’Brien \& Julien, Laboratory Analysis of Mudflow Properties) [8], is expressed:

$$
\begin{aligned}
& \eta=\alpha_{1} e^{\beta_{1} C_{v}} \\
& \tau_{\mathrm{y}}=\alpha_{2} \mathrm{e}^{\beta_{2} C_{v}}
\end{aligned}
$$

Table 1: Summary of the topographic survey.

\begin{tabular}{ll}
\hline \multicolumn{2}{l}{ Topographic survey data of the Pescadores valley } \\
\hline Camera model & DSC-WX220_4.4_4896x3672(RGB) \\
mds Resolution and Orthomosaic & $7.09 \mathrm{~cm} /$ pixel \\
Dots & Average of 57,676 dots per image \\
Images & 657 \\
Calibrated Images & 655 \\
Number of dots & 79671642 \\
Major contour lines & $5.00 \mathrm{~m}$ \\
Minor contour lines & $1.00 \mathrm{~m}$ \\
\hline
\end{tabular}




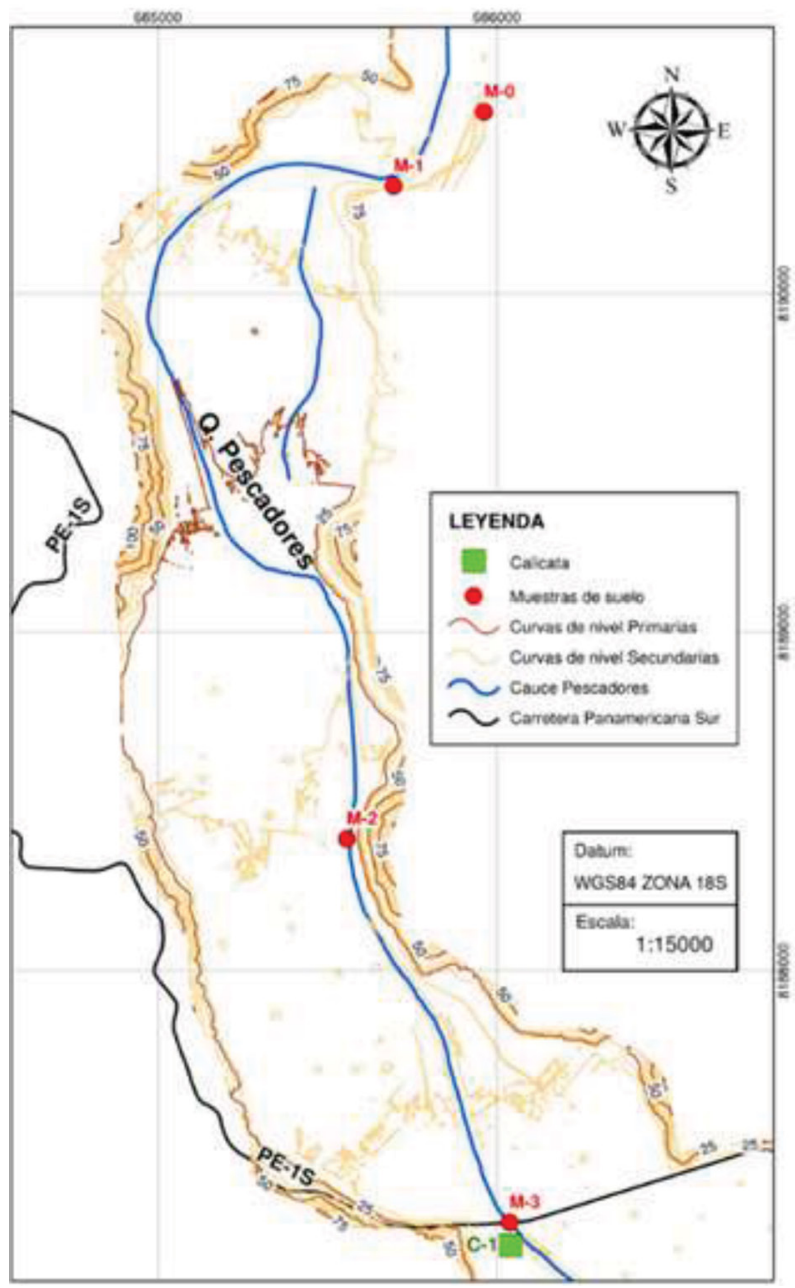

Figure 2: Topography of Pescadores valley in UTM coordinates.

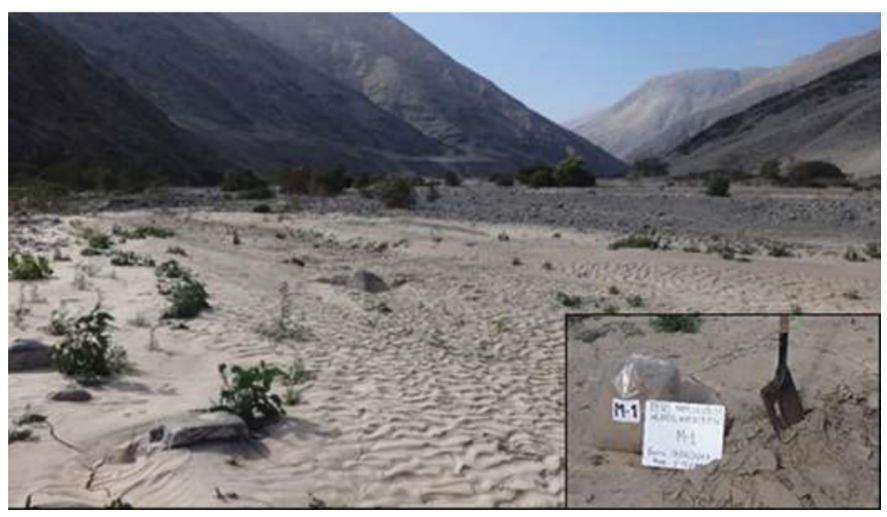

Figure 3: Sample collection in zone M-1. 
Table 2: Result of the tests at the soil mechanics laboratory.

\begin{tabular}{|c|c|c|c|c|c|c|}
\hline \multirow{2}{*}{ Results } & \multicolumn{4}{|c|}{ Sediment size distribution } & \multirow{2}{*}{$\begin{array}{l}\text { Liquid } \\
\text { limit }\end{array}$} & \multirow{2}{*}{$\begin{array}{l}\text { Plastic } \\
\text { index }\end{array}$} \\
\hline & Clay (\%) & $\mathrm{D}_{16}(\mathrm{~mm})$ & $\mathrm{D}_{50}(\mathrm{~mm})$ & $\mathrm{D}_{84}(\mathrm{~mm})$ & & \\
\hline Sample M-1 & 6.10 & 0.011 & 0.034 & 0.059 & 0.404 & 0.012 \\
\hline
\end{tabular}

Table 3: Coefficients $\alpha$ and $\beta$ to determine the yield stress $\left(\tau_{y}\right)$ and viscosity $(\eta)$.

\begin{tabular}{|c|c|c|c|c|c|}
\hline \multirow[t]{2}{*}{ Sample } & \multirow{2}{*}{ Classification } & \multicolumn{2}{|l|}{$\tau_{y}=\alpha e^{\beta C v}$} & \multicolumn{2}{|l|}{$\eta=\alpha e^{\beta C v}$} \\
\hline & & $\alpha$ & $\beta$ & $\alpha$ & $\boldsymbol{\beta}$ \\
\hline M-1 & Glenwood 3 & 0,000707 & 29,8 & 0,00632 & 19.9 \\
\hline
\end{tabular}

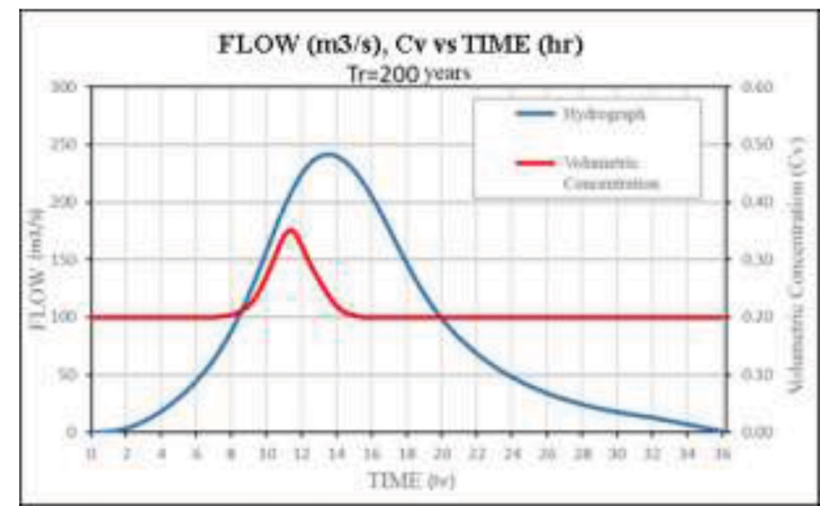

Figure 4: Hydrograph and volumetric concentration of sediments $\left(C_{v}\right)$ for a return period of 200 years.

Where,

$\tau_{y}:$ Yield stress

$\eta$ : Dynamic viscosity

$\alpha_{i}$ y $\beta_{i}$ : Empirical coefficients determined by laboratory experiments

$C_{v}$ : Volumetric concentration of sediments

The $\alpha$ and $\beta$ values were calculated from the samples collected in the field, the results are shown in Table 3.

The rheological parameters such as viscosity $(\eta)$ and yield stress $\left(\tau_{y}\right)$, which are in function of the volumetric concentration of sediments $\left(C_{v}\right)$, by varying this volumetric concentration over time, this makes the parameters of viscosity and yield stress also vary with throughout the development of the hydrograph. Figure 4 shows the variation in time of the volumetric concentration of sediments $\left(C_{v}\right)$, and the hydrograph of the water flow, for a return period of 200 years. 


\subsubsection{Hydrology of the Pescadores basin}

There were no records of maximum flows in this valley; hence, there are no hydrometric stations, only the data for 24-hour maximum rainfall were available at different stations in the considered basin, and this was provided by SENAMHI [9]. For this reason, the transformation of rainfall to maximum flow had to be done with hydrological simulations.

Firstly, we start from the model of the basin that was obtained through the ALOS PALSAR satellite; then, the digital model of elevations and river network of the basin was obtained; and the basin, sub-basins and the river network were delimited. Figure 5 shows the river network and the valley's hydrology basin.

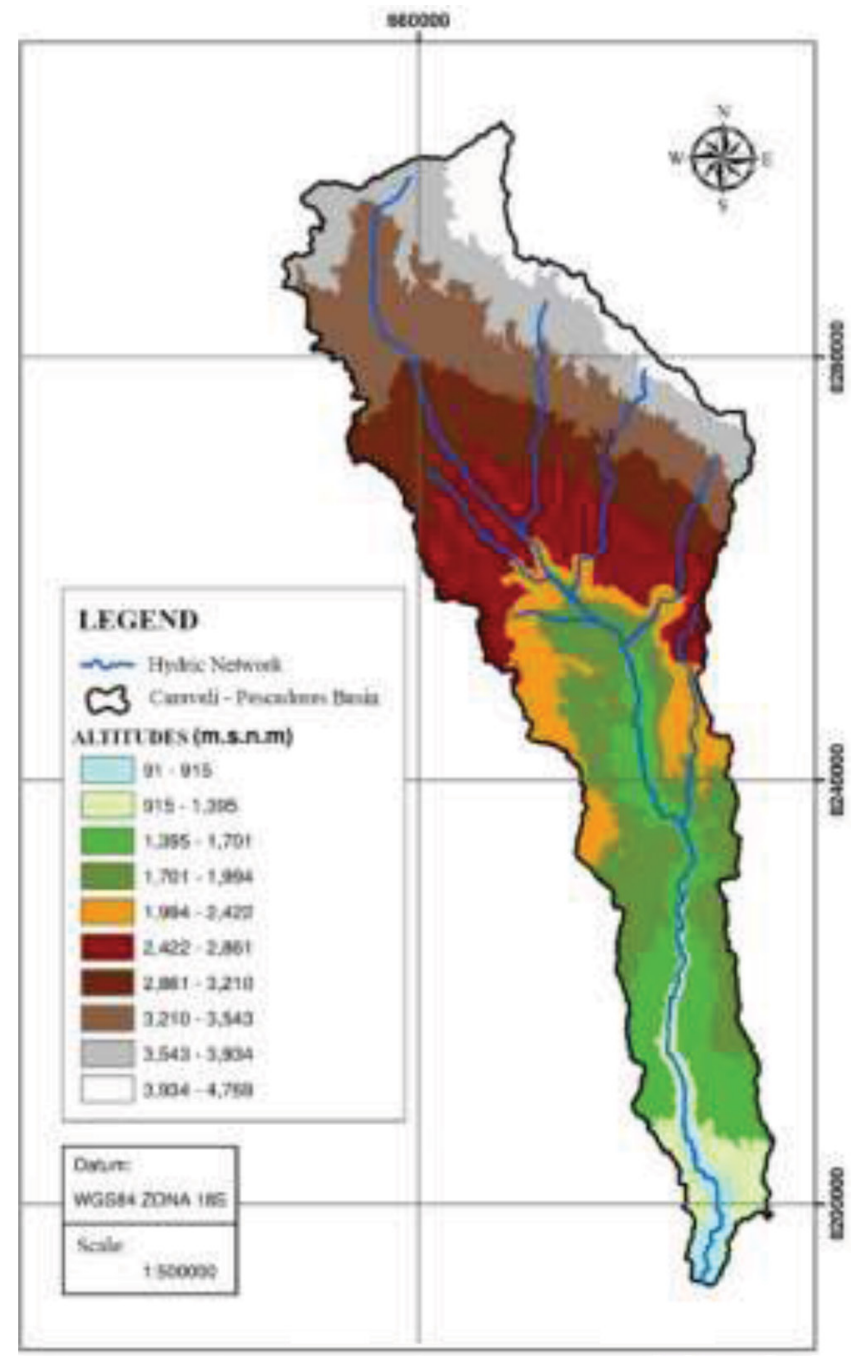

Figure 5: Digital model of elevations and river network obtained from the Pescadores valley hydrological basin. 
The frequency analysis study was performed with different distributions such as Normal, Log Normal 2 Parameters, Log Normal 3 Parameters, Gamma 2 Parameters, Gamma 3 Parameters, Log Pearson Type 3, Gumbel, Log Gumbel [10]; Subsequently, the statistical tests were carried out to see the best fit model, obtaining the precipitation Isohyets for a return period of 200 years as it is shown in Fig. 6, from which the maximum flows were generated.

Subsequently, the meteorological models were entered, which are represented by the hyetogram obtained from the maximum 24-hour rainfall. Then, the control point specifications such as the simulation time, as well as the time interval, were entered. Once the isohyets were graphed, the corresponding areas between each of them were determined, in order to determine the representative precipitation for each of the sub-basins of the Pescadores basin.

For the purpose of the solution proposals, for the design of hydraulic structures, the hydrology has been simulated for a return period of 200 years, obtaining the following hydrograph, which is shown in Fig. 7. The 24-hour rainfall was transformed to maximum flow rates based on the Soil Conservation Service (SCS) dimensionless hydrograph and the synthetic unit hydrograph.

Obtaining an average slope of the main channel of 3.20\%, taking into account that the Pescadores valley basin has an area of $1,954.9 \mathrm{~km}^{2}$, the curve number values were obtained using the SCS method, for which the hydrological group and land use classification was performed in the basin, obtaining an NC of 81.70.

To obtain the hydrographs, the unit hydrograph method of the SCS was used for return periods of 25, 100, 200 and 475 years, obtaining the following maximum flows of $101.70 \mathrm{~m}^{3} / \mathrm{s}$,

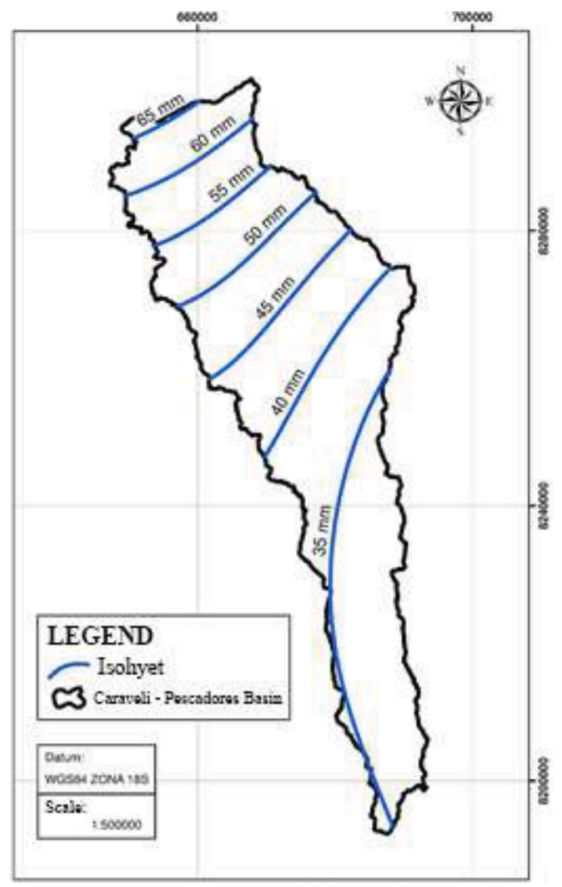

Figure 6: Rainfall Isohyet curves for a return period of 200 years. 


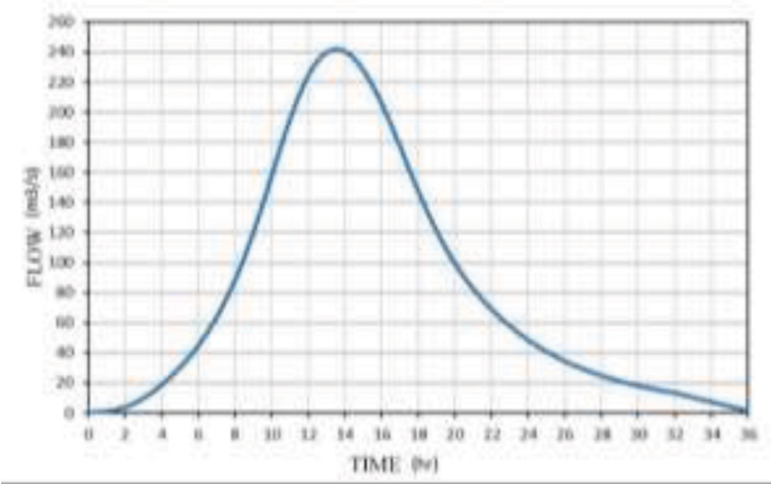

Figure 7: Hydrograph for return period of 200 years in Pescadores valley.

$217.90 \mathrm{~m}^{3} / \mathrm{s}, 241.70 \mathrm{~m}^{3} / \mathrm{s}$ and $289.00 \mathrm{~m}^{3} / \mathrm{s}$. respectively. For the proposed solution, the maximum flow of $241.70 \mathrm{~m}^{3} / \mathrm{s}$ is considered, which corresponds to a 200 -year return period.

\subsubsection{Manning's coefficient (n) in the flood zone}

To determine the values of the channel roughness and the flood zones, the values of Manning's roughness coefficients from Open Channel Hydraulics by Ven Te Chow [11] were taken into account.

In the field, the different roughness components were located by a visual inspection and a comparison with the corresponding bibliography of the simulation area and the riverbed. This parameter is very important since, when calibrating the model, a slight variation of the Manning number will have a great influence on the values of the depth and flow velocity. The map of values of Manning's ' $n$ ' is shown in Fig. 8.

\subsubsection{Simulation and calibration}

Once all the necessary data and information were obtained from the flood valley, such as topography (DEM), hydrology, rheological parameters, Manning number, etc., the computational simulation of mudflow was performed [12] [13]. The first results of the flood maps were calibrated with the data obtained from the field.

The calibration of the model was based on the flood event that occurred on 12 February 2012 in the Pescadores valley [14], which paralyzed the Panamericana Sur highway. The calibration consisted of matching the depth and the flow velocity in a specific cross section, located at the junction of the riverbed with the Panamericana Sur highway, seeking to match the depth and the flow velocity obtained with the computational simulation. The parameter that was modified in the simulation for the calibration is the volumetric concentration of sediments $(\mathrm{Cv})$ and the Manning ' $\mathrm{n}$ '.

Several simulations were carried out until a good match was achieved between the depth and the velocity measured with the simulated one. Figure 9 shows the comparison of depth flow. 


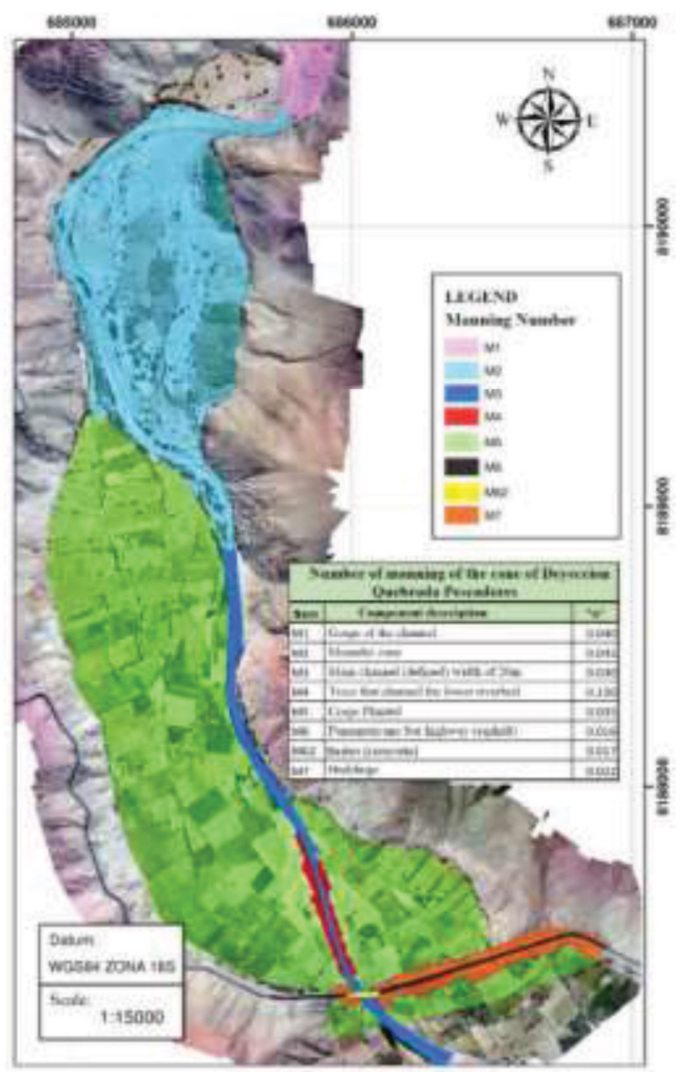

Figure 8: Manning number in the Pescadores valley.

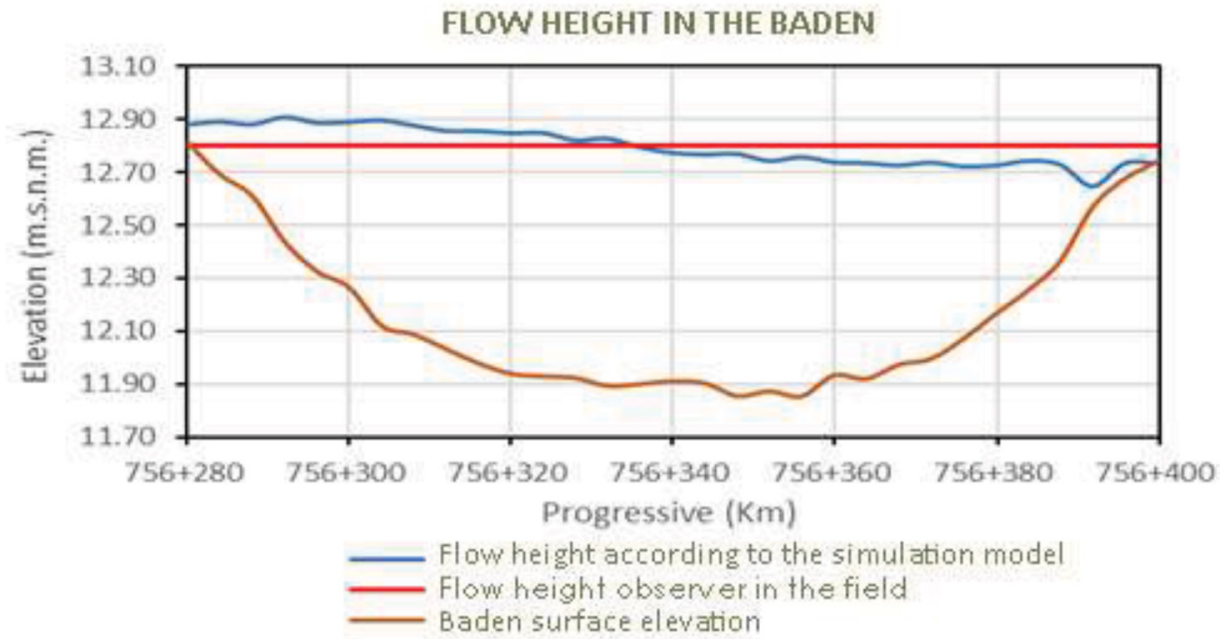

Figure 9: Comparison between flow observed in situ and simulated after calibration. 


\section{RESULTS}

The final result of the simulation after the calibration was for a return period of 200 years resulting a flow of $241.70 \mathrm{~m}^{3} / \mathrm{s}$, from there it is concluded that the depth/flow height in the flood plains varies between $0.40 \mathrm{~m}$ and $3.00 \mathrm{~m}$, and in the channel it reaches a depth of up to $5.32 \mathrm{~m}$. Hence, it is stated that, in the event of a maximum avenue with a designated flow, the Pescadores valley would be mostly flooded, affecting the crops areas and the Panamericana Sur highway would be flooded for a length of approximately $600 \mathrm{~m} \mathrm{[15].}$

The upper part of the valley would be completely flooded, but since this is an arid area that is not cultivated, its protection is not necessary. The depth results of the flood simulation can be seen in Fig. 10.

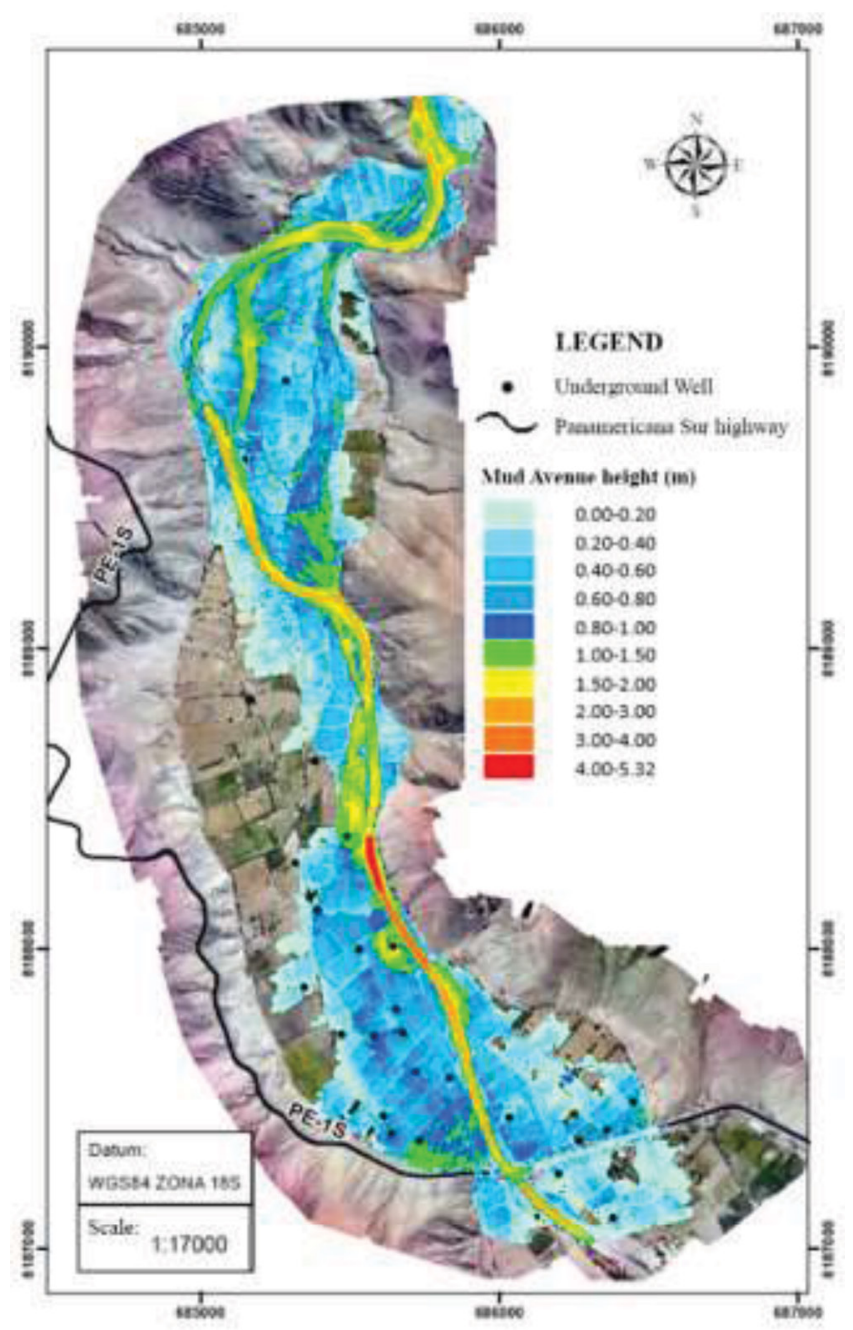

Figure 10: Depth flow resulting from the simulation of a mud flood for a return period of 200 years. 


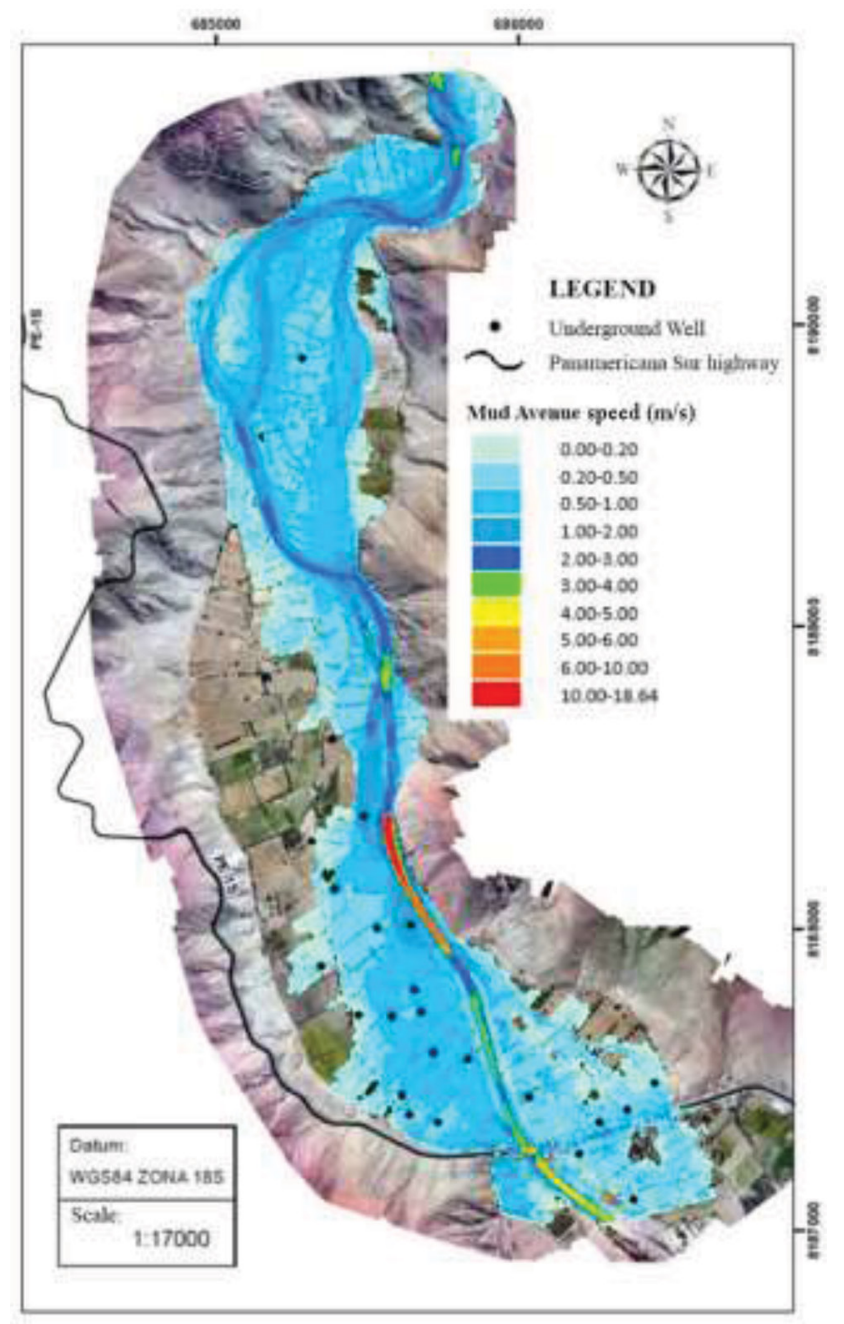

Figure 11: Mud flood simulation speeds for a return period of 200 years.

Then, the flood flow velocity map is presented, resulting from the simulation due to the flood of mud, in which it is observed that the speed mostly varies between 0.50 and $3.0 \mathrm{~m} / \mathrm{s}$, reaching in some localized points a maximum speed of up to more than $18.0 \mathrm{~m} / \mathrm{s}$, being these very dangerous. It can be noticed that the speed decreases as it moves away from the riverbed; the result is shown in Fig. 11.

\section{PROPOSED SOLUTIONS AND SIMULATION}

The proposed solutions are the channelling of the riverbed in order to avoid the overflow of mudflow towards the cultivation areas and the construction of a bridge over the river to avoid blockage of vehicular traffic on the Panamericana Sur highway. Figure 12 shows the location of the Pescadores bridge and the channelling with an embankment dam of the riverbed in the Pescadores valley. 


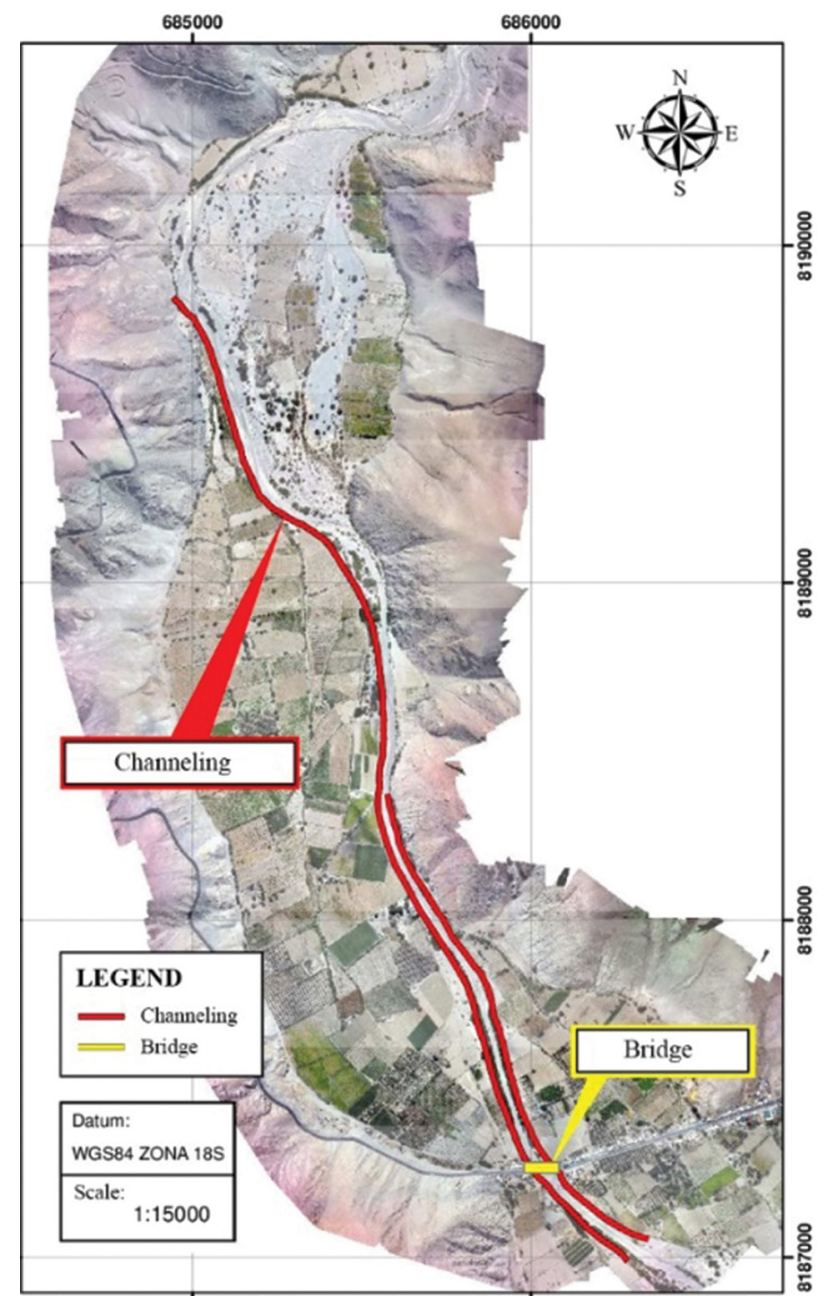

Figure 12: Proposed solution with channelling through an embankment dam and the construction of the Pescadores bridge.

The channelling through an embankment dam, on the right bank begins in the meander zone and ends downstream of the bridge with a total length of $3.0 \mathrm{~km}$, and on the left bank, the channelling has a length of $1.0 \mathrm{~km}$. The stable channelling width was determined according to various empirical formulas, this being $75.0 \mathrm{~m}$ and the radius of curvature of $200 \mathrm{~m}$ [16].

The construction of the Pescadores bridge is necessary in order to avoid the blockage at $\mathrm{km} 756+400$ of the Panamericana Sur highway. This bridge was pre-dimensioned, considering the recommendations specified in the bridges manual and the highway manual of the Ministry of Transport and Communications of Peru. This bridge is located in the same place that the Pescadores Baden currently occupies, it is of the beam-slab type with a total length of $105.00 \mathrm{~m}$. 


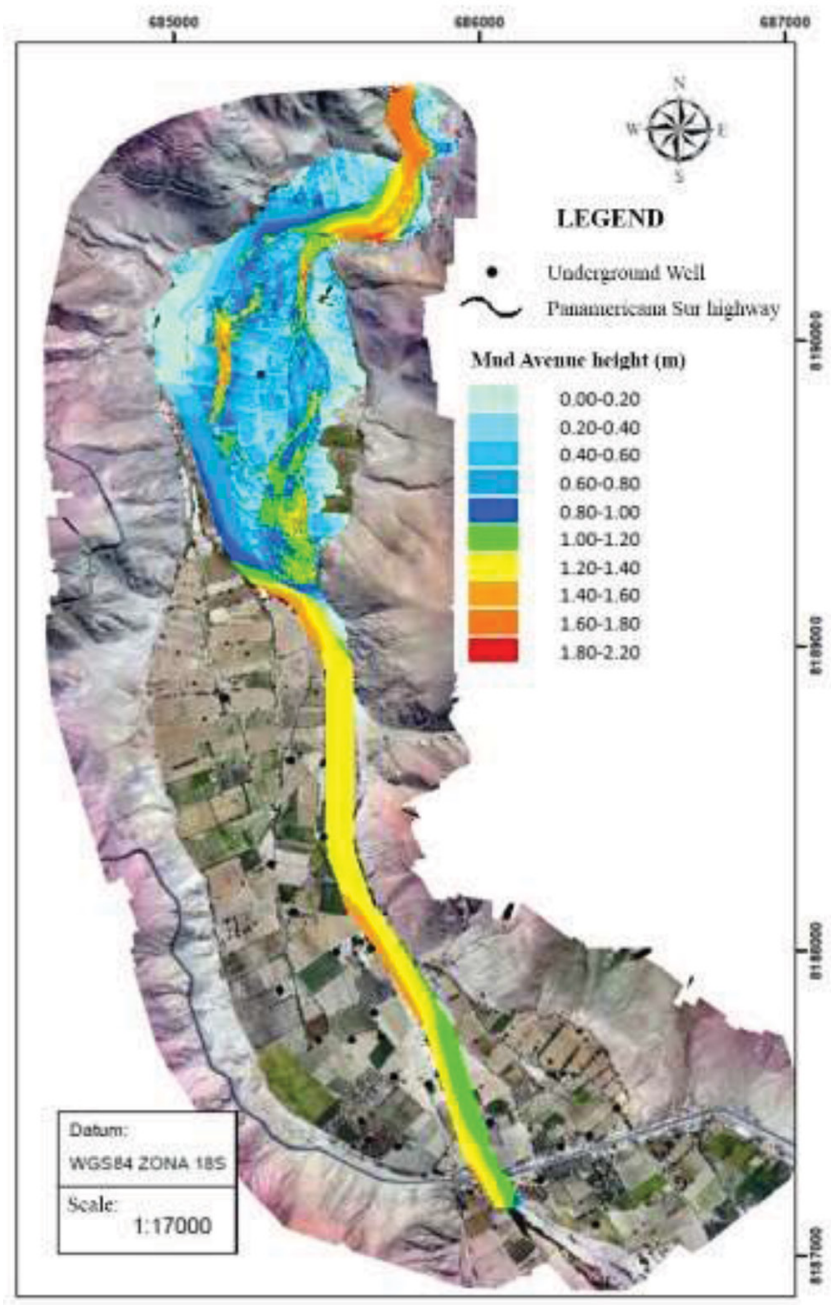

Figure 13: Depth simulation of mudflow flooding after channelling.

With the proposed solutions, the flood simulations were carried out again, from which it can be stated that the Pescadores valley will not be flooded again with flows of up to $241.70 \mathrm{~m}^{3} / \mathrm{s}$, and moreover, the vehicular traffic on the Panamericana Sur highway would not be interrupted. This new simulation is shown in Fig. 13.

\section{CONCLUSIONS}

The estimated cost of channelling the river with an embankment dam and the bridge over the Panamericana Sur highway is approximately four million one hundred thousand US dollars (US $\$ 4,100,000.00)$.

The bridge, as well as the channelling, is designed for a maximum flow of $241.70 \mathrm{~m}^{3} / \mathrm{s}$, which corresponds to a 200 -year return period. The simulation with the solution proposals 
adequately meets its objective by allowing adequate vehicular traffic on the Panamericana Sur highway, mainly at $\mathrm{km} 756+400$, in order to guarantee its operability in the most adverse conditions, and as well as safeguard the crops from the Pescadores valley.

The proposed solution chosen is a bridge of 05 simply supported sections having a total length of 105.00 meters, with prefabricated double T longitudinal beams, an embankment dam, with a right bank of $3.00 \mathrm{~km}$ in length and on the left bank a length of $1.0 \mathrm{~km}$ with a channel width of $75 \mathrm{~m}$.

With a series of samples taken in the field, it was determined that the volumetric concentration of sediments for this valley is 0.35 .

It is recommended to install flow capacity stations in strategic points of the river since there is a lack of those. These stations would provide better tools when trying to calibrate simulation models.

\section{REFERENCES}

[1] Macro consult, sistema de información. Obtenido de , available at https://sim.macroconsult.pe/danos-de-el-nino-us3-124-millones-hasta-ahora-macroconsult/, (accessed 2 march 2019).

[2] O'Brien, J., Julien, P., \& Fullerton, W. T. Two-dimensional water flood and mudflow simulation. Journal of Hydrologic Engineering, ASCE. DOI: https://doi.org/10.1061/ (ASCE)0733-9429(1993)119:2(244).1993.

[3] O’Brien, J. S., \& Julien, P. Y., Laboratory Analysis of Mudflow Properties. Journal of Hydraulic Engineering, ASCE. DOI: 10.1061/(ASCE)0733-9429, 114:8(877). 1988.

[4] Julien P.\& Lan Y., RHEOLOGY OF HYPERCONCENTRATIONS, Civ. Eng., Res. Ctr., Colorado State Univ., Fort Collins, CO 80523. USA1991.

[5] Courant- Friedrich- Lewy, available at https://en.wikipedia.org/wiki/Courant\%E2\%80 \%93Friedrichs\%E2\%80\%93Lewy_condition, (accessed 15 March 2019)

[6] Castillo N., Leonardo F., Aplicación de un modelo numérico de flujo de escombros y lodo en una quebrada en el Peru., Universidad Nacional de Ingeniería, Lima, Peru. 2005.

[7] IGN. Ficha Tecnica PCR-3, Peru, 2017,

[8] O'Brien, J. S., \& Julien, P. Y., Physical processes of hyper concentrated sediment flows, Conference on the Delineation of Landslides, Floods and Debris Flow Hazards, Utah, USA, 260-279. 1985.

[9] SENAMHI. (9 de abril de 2017). Descarga de datos hidrometeorologicos. Obtenido de, available at http://www.senamhi.gob.pe/?p=descarga-datos-hidrometeorologicos

[10] V. Chow, D. Maidment. L. Larry, Applied Hydrology, McGraw Hill Inc: NY, 1990.

[11] V. Chow, Open Channel Hydraulics, McGraw Hill: NY, 1972.

[12] FLO-2D, Simulating Mudflow Guidelines, Nutrioso, Arizona, US, 2018.

[13] Perez, A.V., Perez, N., Perez, A. Flooding simulation and channeling in the valley of the Andes mountain in the south Peru; WIT Transactions on Ecology and the Environmental, Vol 239, 2019, W.

[14] PROVIAS Ministerio de Transportes comunicaciones, unidad zonal XIV, Arequipa, Report 13, Peru, 2012.

[15] Perez A., Huancara R., Cutire F., Perez N., Perez A., Two dimensional of non-Newtonian flow, WIT Transactions on the built environment, Vol 194, WIT Press, FRIAR 2020, Southampton and Boston, pp. 87-98, 2020.

[16] Perez A.V., Orosco J., Quispe V., Encauzamiento del rio Tambo, Universidad Nacional de San Agustin, Arequipa, Peru, 2017. 